\title{
At the Table with Hungry Ghosts Intimate Borderwork in Mexico City
}

\author{
JEAN DURUZ \\ UNIVERSITY OF SOUTH AUSTRALIA
}

I watched [my father] ... make tamales. The masa dough [on the counter] ... Corn husks soaked in a huge pot. The filling-cactus strips and kernels of corn in a chile-tomato sauce-had been ready since morning ... While he worked, he talked ... 'The mouth can talk', he said, 'but tasting is first. Talk is just the translation.' He put some cactus filling in my mouth.

Thomas Fox Averill ${ }^{1}$ Living in the crosshairs of this cultural shift, I am both expression and instrument of it: double resident, hence double agent, in the service of both sides and neither. Spiritual migrant, permanent gringo, riding the tidal currents that surge across this semipermeable membrane, la frontera.

\section{Tony Cohen ${ }^{2}$}

\section{-DEPARTURES, ARRIVALS}

The plane leaves LAX, Los Angeles' airport, and heads south of the border. It seems like cheating to cross in this way-to duck the long queues of cars at checkpoints, constantly recycled in films such as Traffic and Babel. Nevertheless, the sense of border is palpable. Some hours earlier, while waiting at LAX during the 'constrained 
time $^{3}$ that air travel inevitably imposes, I felt haunted by the border's imagined presence: its displacements and relocations, its economies of movement, belonging and loss. Now, as the plane approaches Mexico City, however, this imagined (and actual) sense of movement-of lines of division and the crossing of these-is replaced by the stasis of the view below: a cartography of megalopolis. Gridded into a valley marked by volcanic peaks, Mexico's iconic global city appears as a dense, repeating pattern of streets filled with traffic and of neighbourhoods with squat white buildings, stretching towards the mountains (it is an unusually clear day).

The writing of the French theorist Michel de Certeau haunts my descent. Reflecting on the view over Manhattan from the top of the World Trade Center in the 1980s, de Certeau famously argued that such structures materialise the scopic imaginaries of urban professionals (architects, urban planners, bureaucrats) and 'construct the fiction that creates readers, makes the complexity of the city readable, and immobilises its opaque mobility in a transparent text'. ${ }^{4}$ Meanwhile, 'The ordinary practitioners of the city live "down below", below the threshold at which visibility begins. They walk....' In the company of ghosts then-border-crossers, planners, 'ordinary' city dwellers and a cultural theorist-I stare through the plane window and find Mexico City's 'immense texturology' as a 'panorama-city' overwhelming. ${ }^{6}$

This article is a meditation on borders, cities and people's everyday practices of belonging and exchange, in contexts of diasporic movement and transnational identity. Its aim is to address some related questions about difference and exchange of cultural meaning within the everyday of global cities. Crucially, these questions focus on how people live together, how boundaries of difference are strengthened, crossed or permeated, and how insights from postcolonial theorising might shape analyses of these concerns. I have been worrying at such a project in its general outline for some time, and from various perspectives. ${ }^{7}$ Threads will be unravelled here to ascertain whether these can be productively drawn together for conceptualising daily, accretional moments of living-in-transculturalism. ${ }^{8}$ (And here I am borrowing from Ien Ang's 'together-in-difference' to suggest the 'lived' experience of identities that, in the minutiae of daily life interactions, recognise, yet transcend, cultural boundaries. $)^{9}$ In many respects, the argument presented here becomes a very personal one. Not only does it emerge from narratives of food 
exchanges within relations of intimacy, but it also allows, for me as author, a (somewhat nostalgic) return to a particular theorist who has become a familiar figure in my writing. Let us begin this journey in the company of de Certeau and others to signal, conceptually speaking, the potential presence of particular hungry ghosts at the table of interview memories and their analysis.

\section{-CONNECTING AND DISPARATE THREADS}

Walking 'down below' through the streets and neighbourhoods of Mexico City, I am interested, first of all, to explore how well de Certeau-this favourite companion for intellectual pursuits-has travelled with me. How much of his theorisations of 'tactics', for example, as 'tricky and stubborn procedures that elude discipline without being outside the field in which it is exercised' or of '[h]aunted places' as 'the only ones people can live in' belong to a specific cultural history of flânerie (think Benjamin strolling through the Arcades or Baudelaire) and to a poetics, quintessentially, of Paris? ${ }^{10}$ Despite his Latin 'epiphany' as a member of the Jesuits in Brazil, Argentina and Chile, ${ }^{11}$ does de Certeau translate readily to the political economies of frenetic movement in the zócolo of Mexico City or the calm behind the locked gates of the family hotelito that has become my second home?

A second thread has already surfaced in this travel narrative. The emphasis on borders, or rather the border, la frontera-the United States/Mexican border-and its resonances of freedom/containment, of first and third world divisions, is a common trope in postcolonial literature, particularly for scholars working (sometimes geographically) within its thrall. ${ }^{12}$ I'd like to put this imagery to work, however, in a somewhat different way, drawing on Bob Hodge and John O'Carroll's conception of borderwork as a dynamic project for identity-making-as active recognition of multiculture's 'permeable boundaries and fuzzy categories' when groups defined by difference are obliged to occupy the same urban spaces. ${ }^{13}$ Attention to examples, both of border permeability and intractability in intimate, everyday interactions, should prove instructive for conceptualising the uneasy post of postcolonial nations and of global cities, haunted by the living ghosts of colonialism, diaspora, memory and loss. ${ }^{14}$

The third thread takes us to the realm of the body itself as a tangible expression of both cultural boundary and of intercultural crossing. A focus on how people eat, 
and eat together within relationships shaped by 'different' histories of diaspora and relocation, might provide hints of their everyday 'borderwork'-cumulative practices towards shaping identity and alimentary belonging. '[I]n eating, we find ourselves in various assemblages, produced and producing ourselves anew' says Elspeth Probyn. ${ }^{15}$ Sneja Gunew, in her turn, signals the significance of visceral knowledges within the politics of intimate exchanges between people, and between people and places. Reflecting on the soundscapes of 'home' for the traveller returning, or the power of a simple gesture, such as a casual wink between men (two strangers acknowledging their shared masculinity), Gunew discovered she had developed a 'pervasive curiosity concerning the ways in which a body might be at ease, provisionally at least, in that dance of somatic gestures which, like tribal markings, indicated precisely this-a language of belonging to a wider community'. ${ }^{16}$ Similarly, I am eager to pursue, in the rituals of sharing food, the comforts of provisional belonging through the senses-embodied negotiations with difference (the tasting of 'home', the tasting of not-quite-belonging) held in delicate balance. After all, as the tamale-making father in the article's opening quotation declares, 'tasting is first. Talk is just the translation'.

The approach to these threads- 'tactics', 'ghosts', 'borderwork' and 'bodies'is through narratives from interviews with an Australian woman, Gini Taylor, who, since 1968, has considered Mexico home, and her Chinese-Mexican partner, René Lee, whom she married in Mexico City more than thirty years ago. Analysis of curious moments in the couple's intersecting culinary histories identifies much fluidity in their practices of eating together-in this household's imaginaries of 'China', 'Sydney' and 'Mexico City', for example, or in its constant juggling of emotional landscapes of 'here' and 'elsewhere'. Through this analysis, a company of hungry ghosts appears at the dinner table-ghosts of diaspora and cosmopolitanism, nostalgia and memory, gender and ethnicity, home and belonging. Attempts by household members to entertain ghosts' competing claims, however, tend to disrupt the transparency of seemingly comforting accounts of familial commensality. At the same time, the micro-tensions of intimate eating within contexts of difference-the dynamics of food, bodies and cultures meeting at the table, and complicating 'border' exchanges-resonate with creative possibilities. 
Of course there is potential, in a project like this one, for other conceptual hauntings, such as Sudesh Mishra's account of diasporic criticism's 'three pillars''transnationalism, modernity, and globalization' ${ }^{17}$ Nevertheless, my intention here is not so much to rework, theoretically, diaspora's grand narratives in any substantial fashion, but rather from the 'inside' of the everyday, to shade in too often absent details, ${ }^{18}$ to puzzle over fragments of remembering-their rough edges and contradictory textures. Similarly, it is not my intention to chart Mexico's social and political history in any definitive sense, and I suggest readers look elsewhere for contextualising accounts of inequalities and social divisions in contemporary Mexican society. ${ }^{19}$ Instead, my overriding concern lies with moments of bordercrossing within personal narratives, and the intimations of the 'lived' politics and positionings that shape these moments. We begin with Gini's story.

\section{-CHILDHOOD IN A CHEESE SANDWICH}

Gini Taylor, born in Sydney in the 1940s and growing up in a household of sevenher parents and their five children-remembers, at an early age, entering an apprenticeship in home cooking. When her mother resumed paid work, Gini and her older brother became responsible for cooking the family's evening meal:

I had to learn ... There were seven of us ... so, you know, it was something for a twelve year old. ... But mum would say in the morning ... 'We are going do this and this and this' and my brother and I laugh now, because ... it was just um boiled potatoes and boiled carrots ... And ... a neighbour also took me in and showed me how to make sweets, you know, like pies, cake ... And I loved doing that, and to ... [this] day ... I can cook a cake like $\ldots$ a fruit cake ... [or a] rice pudding or blancmange or custard...20

Having been schooled in the traditional cooking of her English parents ('We had very plain food ... With just a touch of curry'), Gini was taught to avoid garlic as the taste of the 'other' ('My mum would never use garlic. She was English...'). ${ }^{21}$ Later in the interview, Gini elaborates on this necessary connection of ethnicity, class and food refusal: 'it was ... not gentrified to eat garlic. My mother and, you know, my mum wasn't from the upper class but my aunts were, and it was like uncouth ... to eat garlic'.22 A curious but historically understandable phenomenon emerges here, in regard to 'foreign' inflections in the 1955 diet of a Sydney Anglo-Australian 
twelve-year-old: while a 'touch of curry' is acceptable, the taste of garlic is not. David Burton points out that British people have had a 'love affair with spices stretching back 1500 years, long before they heard of Indian cooking'. He argues that, strengthened by British colonial rule and persisting with Indian independence, British taste for curry 'has remained unbroken to this day'. ${ }^{23}$ On the other hand, rejection of garlic, particularly in the postwar period, might be interpreted as 'the last-ditch defence of the British against the onslaught of food of other [noncolonised] nations. ${ }^{24}$ 'Other nations' in this case were particularly those of southern Europe, such as Italy, France and Spain-mythic landscapes of dangerous sexual and gastronomic excesses. ${ }^{25}$ Ghosts of Britain's 'proper' colonial heritage and the hedonism of the 'improper' Mediterranean 'exotic' are at play in this culinary remembering, producing residual tastes in everyday immigrant and diasporic placemaking.

The 'plain' of a traditional British diet in childhood, however, is severely challenged by the culinary possibilities of young adulthood in the inner-city suburbs of Sydney during the early 1960s - an age of 'epicurean outburst', according to Michael Symons, although disputing its mythic postwar migration origins. ${ }^{26}$ There is no doubt, however, that for Gini, as a student and especially later when living in a shared household in Balmain (a suburb with a tradition of boat-building, pubs, working class left politics and intellectual and artistic bohemianism), ${ }^{27}$ this was a time in which she discovered new communities of taste:

I was about eighteen when I knew about ... [other cusines]. Yeah, we would go down to Sussex Street ... to eat Chinese on Friday night. ... And, um to the Greek restaurants around Sydney, I remember that. And maybe Italian in those days.

And when I moved out [of home] to Balmain then I started, for example, [preparing] cabbage. I'd have this dressing that I used with garlic, oil and vinegar, and, you know, we didn't have much money as students ... And we would make this huge coleslaw with garlic .... Spanish people would come to the parties ... [and] I remember learning that recipe from a Spanish guy. ${ }^{28}$

Such tastes, together with a sense of gastronomic adventurousness, were to stand her in good stead, for in 1968, following several months of working in London and in 
the wake of the student movement and massacre of protestors at Tlatelolco (ironically, a site of Cortéz's conquest of the Aztecs in 1521), ${ }^{29}$ Gini set out for Mexico City.

Nearly forty years later, we join Gini, now a fluent Spanish speaker and permanent resident in Mexico, an academic and joint-owner (with husband René) of a student hostel and café, mother of two sons and soon to become a grandmother. Nevertheless, she is haunted by the image of a cheese sandwich as a nostalgic taste of 'home'. This is not surprising, and echoes the home-making practices of many immigrant and diasporic groups, with 'home' remembered as particular tastes, textures, colours, shapes, smells and sounds associated with food, cooking and eating. ${ }^{30}$ Commenting on Mexico's gastronomic cultures, household divisions of labour and her own negotiations with these, Gini says:

You know ... 'Give me a cheese sandwich, what's the fuss about?' ... it's taken me a long time to eat slowly, for example ... to take time over food and all that. It's been a whole learning process for me. But ... [René] will make judgements about ... [any woman who doesn't spend time cooking]: 'she's just lazy, you know'. [I reply]: '[0]h cut it out ... This food that you've got has a lot to do with the condition of women, you know, it's not that she's lazy she's just got other priorities.' [T] hey're very judgemental about that sort of thing and it makes me angry. ${ }^{31}$

There is obviously more to this story than memories of childhood's 'plain' tastes-those imaginaries of white bread and processed cheese that represent Anglo-Australia's increasing adoption of convenience foods during the 1950s, and recalled here with a Proustian force. ${ }^{32}$ Although celebrating the comforts of a cheese sandwich, there is also tension in this tale's telling. The implication is that bordercrossings and exchanges across boundaries (whether between nations, culinary cultures or bodies in relations of intimacy) are not so simple, after all. Consent is never absolute. So, is this an example of de Certeauean 'tactics' at play here-those 'tricky and stubborn procedures' that gnaw at, and yet operate within, the disciplinary boundaries of regimes of gender and ethnicity, for example? Perhaps. However, to date these are simply ghostly traces of how de Certeau's 'ordinary practitioners of the city live "down below"'-occasional hints of theoretical possibility for this analysis. To confront more fully the explicit dynamics of meeting 
and eating at these particular borders (and their potential for productive moments of intercultural 'fuzziness'), ${ }^{33}$ it would seem useful to 'thicken' the account with narrative fragments from the other side of the story: René's memories of childhood tastes, resonating both of 'China' and 'Mexico'.

\section{—MOORS, CHRISTIANS AND COOKING FATHERS}

René Lee, born in the mid 1930s, grew up on his father's tomato plantation near the town of Bamoa in Singaloa, one of the states bordering Mexico's west coast. His father was Cantonese, his mother Mexican. The two gastronomic traditions that René's parents (as a couple) inherited were maintained separately in the household's cooking, according to the dictates of gender and ethnicity. Chinese migration to Mexico is not, in itself, unusual (originally based on the establishment of Mexico, as New Spain, as a stopping point on the sixteenth-century trade route between Spain and the Philippines). ${ }^{34}$ However, as Ang points out in response to celebrations of hybrid identities and fusion of ethnicities within Australian households, the internal dynamics of interethnic marriages are barely understood. ${ }^{35}$ In other words, and for my project here, there has been little attempt to cross these 'different' thresholds of intimacy to document everyday negotiations in relation to who cooks, what is eaten and when, and the reasons for this.

For René, there existed a strictly observed daily division of labour in food preparation, with his mother cooking Mexican food each day for one of its main meals, his father Cantonese for the other. As an enthusiastic eater, René recalls that one of his most comforting memories of childhood is derived from his mother's daily presence in the kitchen and her repertoire of traditional Mexican/Hispanic dishes. Gini begins the story:

one of the things that has always amazed me with René is his association [of food] with affection, you know, like his favourite comfort food is beans and rice together. It's called ... Christians and Moors, that's how they call it. Because you've got black and white...

René (with Gini translating) continues:

At four or five o'clock in the afternoon my mama would say 'Would you like to eat something?' ... And she would give me rice with beans and chilli. 
... And sometimes with an egg. A fried egg on the top of the rice. That was always with a sauce...

Jean: Sounds delicious.

René: Now that I'm grown up I remember back to that, and that's what I miss and that's what I like ... It's what I most associate with my mama. ${ }^{36}$

So, while the dish of Moros con Cristianos (Moors and Christians) is, in fact, 'a reminder of the Moors' place in Spanish history; a visual as well as a culinary reference with the black beans and white rice, ${ }^{37}$ here it is embedded within the remembrance of a particular childhood-a childhood marked by gastronomic hybridity, and one in which the mythical figure of Cooking Woman provides, and demands nothing in return. ${ }^{38}$ After all, for René, there was no obligation to learn to cook or to help his mother in the kitchen (and, in fact, he says, this was 'not usual for men'). ${ }^{39}$

In contrast, when his father cooked, René was by his side and, from him, learned the precise arts of Cantonese cuisine. This is fitting as, according to $\mathrm{Yi}-\mathrm{Fu}$ Tuan, 'Perhaps no other civilization has put as much emphasis on the art of cooking or taken so much pleasure in food as the Chinese' ${ }^{40}$ Furthermore, this father-to-son act of cultural transmission echoes in a microcosm the re-establishment of an 'old' cuisine in the so-called 'New World': in the globalisation of Chinese food through its diasporic communities, Cantonese cuisine has spread, not only as in its haute cuisine forms but also as peasant food, particularly with those Chinese labourers leaving Guangdong from the nineteenth century onwards. (They invented the "chop suey" dishes, which dominated the food style served in Chinese restaurants in North America until about the 1970 s. $\left.^{\prime}\right)^{41}$

Nevertheless, in spite of his culinary heritage, René's cooking father was an unexpected sight for Gini during her first years in Mexico, although later her sons were to reap the benefits:

Gini: His father was an excellent cook. And I asked the ... [obvious] question: 'How come a man is doing the cooking?' ... [It seemed that his] father cooked because ... they had a Chinese cook ... [on the] tomato plantation. And they brought out a Chinese cook, and he cooked for the workers and for the family. And I think the father learnt to cook from him. 
René (Gini translating): It's not true in China the men do not cook. All the Chinese men that came to Mexico knew how to cook, including my father. Gini: And the one thing [of the culture] that ... [René's] given to our children, the only thing that stayed was the food. I mean he knows nothing about China ... He doesn't speak Chinese ... [because his] father was always working, but the one thing that stayed ... is the food. And they had very special techniques in the family, like when it's a special day or that it's Chinese [food being cooked], and my sons cook Chinese food very well. ${ }^{42}$

In this narrative, then, there is evidence of a cultural legacy persisting from one generation to the next. René, either as eating child or cooking/eating father, might be seen as doubly fortunate: as inheritor of the 'taste' of both China and Mexicoboth cuisines with 'ancient flavouring traditions, many of them thousands of years old, [that] persist unchanged to this day'. ${ }^{43}$

However, there is a more idiosyncratic way in which this narrative intrigues me-and one that goes beyond assuming doubled 'enrichment' possibilities for hyphenated identities. Although Ang complains of 'the prisonhouse of Chineseness'-essentialised identity expectations attached to diasporic communities-it seems from the story above that some identities inherited from diaspora may have a degree of expedient mobility, after all. ${ }^{44}$ Here, in the course of a household's single day, one might move from the position of indulged boy child, nurtured in the Mexican kitchen and discouraged from participation in the ritual labours of meal production, to the position of competent cook-in-training, expressing one's Chineseness and masculinity in acts of cultural apprenticeship and father-son bonding. Either position is, potentially at least, one of comfort and affirmation. For Gini, however, with her 'outsider' status (neither Chinese, Mexican or a fusion of the two), this apparent ease with different cultures and identities vested in hybridity-forms of inherited border-crossing-is more elusive, and produces, in her, much more contradictory reactions. While approving the generational legacy bestowed on her own sons (their grasp of family secrets in the form of 'special techniques'), at the same time, she disparages the processes that render her own belonging contingent, incomplete: 
For me to cook was something you had to get over and done with quickly whereas René will take hours. You know, cutting the carrots ... it drives me nuts ... You have to cut the carrot at a certain angle. And if it's not cut at [that angle, it's incorrect]. ${ }^{45}$

The balancing act of approval and irritation, of at once feeling 'at home' and feeling alien, expressed through the mundane details of everyday life ... a cheese sandwich, carrots sliced in prescribed ways-is this de Certeau's city 'down below', muddied with the tensions of daily practices? Does this suggest that border-crossing (at least for the stranger) is always a prickly business, full of ambiguities, odd doubts and certainly never equivocal or complete? After all, Gunew reminds us, diaspora is 'an endless process of travelling and change rather than simply being framed by leaving and arriving, with mourning and nostalgia as its dominant markers' ${ }^{46}$ It should be noted that Gunew's emphasis here, quoting Lim, is on 'continuing relationships with the location of origin' rather than on the more usual meanings of diaspora as enforced movement without possibility of return. Hence Gunew's preference for 'transnationality' to 'diaspora', to signal a sense in which the project of identity, based on multiple place attachments, always involves unfinished business. ${ }^{47}$ So, then, if '[h]aunted places are the only ones people can live in', the ghosts of these liveable landscapes simply cannot be assigned to the 'past'. ${ }^{48}$ Instead, such landscapes are produced on a daily basis by people's continuing engagement with ideas of home and belonging. 'Home' retains its immediacy and mobility in memory and imagination, with the hungry ghosts at the table never quite satiated. To further 'thicken' this analysis, we shall now focus more centrally on food and food exchanges within relations of intimacy-within bonds of marriage, family, community.

-POSOLE, WHOLE FISH AND THE GRINGA WHO CAN'T COOK

At the age of sixteen René leaves home and the familiar kitchen of nurture and bonding to finish his schooling in Mexico City. Twenty years later, although his cooking repertoire has expanded to include simple Mexican dishes, he is still the focus of maternal solicitude. Gini recalls the early years of their relationship:

when I [first] knew René he was living in ... an old building and all the little old ladies used to send him um flans [custards] ... because he, you know, 
was their little adopted... [son]. And they were always saying this ah gringa (me) ... you know, poor René ... he must be eating ... terribly with her.

Jean [laughing]: Yeah. ...

Gini: it was always a way of putting me down too. ${ }^{49}$

It seems that, in the absence of Cooking Woman-mother or 'proper' wife-René clearly becomes a displaced person, but one, by virtue of his masculine status, fully entitled to care.

Fortunately, a neighbour takes Gini in hand to teach her traditional Mexican dishes, such as posole (a stew of pork and corn kernels, with eighteenth-century folk origins in a tale of the inventiveness of Chilapa women during a visit from the Archbishop of Puebla). ${ }^{50}$ Together, Gini and the neighbour go to the market to purchase a pig's head and, returning home, begin to prepare the dish:

And I'll never forget ... I had to stand there shaving the pig's head, and its nose and everything ... Ahhh and the ears, you know, get the wax out of the ears ... I thought 'How am I going to eat this?' And [my neighbour] ... said to me ... 'the pig's head, it's because of the gelatinous nature of it ... and it's very important, you need that. Posole without a pig's head is not posole.' And ... [later] I became very famous in university for my posole ... It was ... [v]ery cheap and ... whenever we have, or my sons have a party, we make posole ... because everybody loves it and it's not so much work. ${ }^{51}$

It seems that, with instruction, the gringa who can't cook can be rehabilitated after all, and achieve some degree of expertise in producing ritual tastes for her community. Furthermore, Gini's sense of revulsion from her initial confrontation with the pig's head-in her eyes, the material culture of the grotesque-is transformed over time to become an easy familiarity with posole's ingredients, embedded in place memories of belonging. At the end of the day, and of forty years' place-making, posole is accommodated in Gini's culinary biography as a pleasurable taste of her Mexican 'home'.

Nevertheless, the shock of this first encounter-a sign of the discomforts of borderwork within 'different' marriages and families-is replicated when Gini and 
René visit Gini's parents in Sydney. On this occasion, René cooks a whole fish. Gini continues the story:

And he put it on the table and my mother started screaming ... I was really angry with her, you know, because there was more going on than the fish. I felt that it was a rejection of René and there was a lot of other stuff going on there ... And [she said]: 'Get that off my table.' I said, 'Mum, it's fish and, you know, if you've got the head on it, he eats the head and he eats the eyes ... and he likes it, you know.' And she said, 'Take that off there.' And then literally she'd only eat, you know, seen filleted fish. 52

This incident, in which the appearance of taboo foods arouses fear and suspicion, is not an unusual one. Ghassan Hage, for example, discussing Lebanese migrants' domestic food practices in Sydney in the 1970s, records a story of Anglo-celtic neighbours' negative reactions to dishes containing raw meat. ${ }^{53}$ (There is a twist to this tale, however, as later, these same neighbours demand an invitation to share this food.) Certainly, Gini's story seems an archetypal one of the clash of cultures, values and practices at the border. Differential designations of foods (as acceptable, as forbidden), according to where one is located, increase the potential for exchanges to be problematic ones and the presence of likely sticking points.

However, I would like to take this analysis on a less predictable route. Instead, these three moments in Gini's storytelling-the culinary incompetence of a gringa, the making of a celebrated posole cook and the terrifying appearance of a whole fish in a Sydney kitchen-suggest ways to move beyond celebration of a migrant's gradual acculturation in the new 'home' or beyond demonisation of the 'old' one as lacking in tolerance. Here, while 'walking' with de Certeau, we might argue that Gini makes a number of 'tactical' moves that, for each of the narrative moments she selects, offer measures of resolution. We should note that resolution not only applies to that time when these incidents actually occurred, but also now, retrospectively, in the telling. In the narration of each of these incidents, Gini achieves a certain degree of identity mobility. Her position often seems one of discomfort (as an inadequate cook and hence not a 'proper' woman, as the stranger confronting unfamiliar ingredients and hence 'out of place' in, and needing induction to, the culture, as the returned traveller estranged from, and embarrassed by the rigid mores of her 'own' culture). A series of subtle moves, however, hint at 'the tricky and stubborn ways' in 
which identity moves to another place, resolving some of the tension felt. ${ }^{54}$ At the same time, these 'tactics' do not challenge, fundamentally, the authority (ideologies, myths, imaginaries, conventions) that contain such moves. These moves, for example, might amount to bringing a feminist consciousness and critique to the situation ('they're very judgemental about ... [women not spending time cooking] and it makes me angry'; old women sending René food 'was always a way of putting me down too'). Alternatively, such moves might constitute acquiring the culture's knowledge and skills, but on one's own terms and in ways connected to one's own history and politics. Gini, for example, as 'famous' posole cook, accommodates a traditional dish in her cooking repertoire without compromising her feminist principles-it's 'cheap ... and not so much work', she tells us-and in ways, in fact, reminiscent of her own student cooking in Balmain. Posole, in the process, is deexoticised, and references a continuing history of resourceful cooking, flavoured by the 'tastes' both of earlier and later belongings.

Perhaps the most interesting shifts in identity, however, are suggested in the final narrative fragment. Here, in her mother's kitchen, Gini occupies the border zone between competing definitions of 'home': between her original and adopted cultures, between imaginaries of whole fish and those confined to fish fillets, between Anglo-Australia and Chinese-Mexico. Despite the tensions of this positioning, Gini becomes the cultural bridge, the figure of the 'transversal enabler' that Amanda Wise describes within urban and rural Australia's multiethnic communities. ${ }^{55}$ It should be remembered, nevertheless, that the actions of Wise's 'enablers' tend to be benign ones, vested in a desire (mostly from the host culture) to foster actions of intercultural reciprocity. Gini's 'enabling', in contrast, is fuelled by anger, or at least a degree of crankiness: the position she adopts on returning to her 'other' 'home' (Sydney) is not one of facilitating the 'other's' positioning in the mainstream culture, but quite the reverse-of causing the mainstream to confront, in visceral sense, the realities of the 'other's' difference. Recognising 'rejection ... and a lot of other stuff', Gini demands that Mexico City's ghosts of 'different' eating are repositioned in Sydney as someone else's 'everyday'. At the same time, the ghosts of the mother's loss-the loss of her daughter to the domain of the 'other'-are poignant reminders of the costs of diaspora for those who remain at home. 
- 'Rubbing along' in MeXico City

These reflections on 'home' and transnationality, emerging from the spaces of Gini and René's kitchen in Mexico City, have travelled a long way from earlier reference to de Certeau's cartographic gaze over Manhattan or his walks through the city as a thoughtful pedestrian. So now I want to interrupt the rhythms of domestic food preparation, and briefly turn the gaze back towards de Certeau himself. Of course, the ghost that some writers claim they glimpse in de Certeau's writing-the 'heroic [male?] pedestrian' who operates resistantly within 'technocratic space [envisaged] as universal'-is not without criticism. ${ }^{56}$ So, following in this figure's wake, we might ask: how helpful is de Certeau's theoretical account of the everyday for journeys beyond the built fabric of Western cities and their cultures of consumerism? ${ }^{57}$ How portable is this account's conceptual baggage ('ghosts', 'walking', 'tactics') for postcolonial borderwork on 'different' forms of diasporic place-making-on 'different' gendered, classed and ethnicised markings of 'public'/social space?

Highmore comments that, for some Anglophone writers, such as Tony Bennett, de Certeau's somewhat elliptical approach denies the possibility of developing coherent explanatory frameworks for positioning specific everyday practices within the tension produced by governmental forces, on one hand, and people's negotiations with these, on the other. Instead of 'adequate sociological or historical description' of such practices, says Bennett:

what is offered is a poetics of the oppressed, an essentially aestheticising strategy in which the prospect of understanding the specific logics informing specific forms of resistance is traded in, far too easily, for a generalised account of 'transgression' ${ }^{58}$

Highmore himself disagrees, calling for a much more nuanced reading of the relationship of institutionalised power and everyday practice in de Certeau's writing:

[de Certeau's] two perceptions (the extension of power and the everyday as non-reducible to it) produce an asymmetry of tactics and strategies where inventive and sluggish practices exist alongside 'proprietary powers'. Different forms and logics are at work, but their non-symmetrical combination results in the friction of 'rubbing along', rather than in direct conflict. $^{59}$ 
Buchanan similarly adopts this argument of asymmetry, representing de Certeau's project as 'the obverse side of Foucault's analyses, looking not for patterns of resistance, which Foucault postulates anyway, but subtle movements of escape and evasion'. ${ }^{60}$

For journeys of reconnaissance across the border then, de Certeau's 'walking' is a suggestive mode of travel. It offers neither a 'generalised account of oppression' that lacks historical or cultural specificity, or an account, although specifically grounded, that reduces the complexity of social relations and their analysis to binary oppositions. Instead, de Certeau offers a point of entry, at the very least, to the 'rubbing along' of everyday life in Mexico City, including that of its intimate diasporic relationships. The subtle shifts of positioning that I've traced, particularly within insider/outsider dimensions of belonging in Gini's narratives, imply neither submission to disciplinary force nor acts of resistance to this, nor even an explicit compromise that requires the careful balancing of agency and constraint. These 'movements of escape and evasion' allow Gini simultaneously to approve and disapprove of cultural practices (her sons' cooking, the slicing of carrots), to feel at 'home', and yet not (domesticating posole, at the same time yearning for a cheese sandwich). Together these moves constitute a 'tactical' repertoire, containing elements of critique, accommodation, tension, anger, pleasure and nostalgia; together, these describe spaces to 'elude' rather than confront 'strategic' forces of power that permeate the everyday of living-in-transculturalism.

However, this analysis of hungry ghosts at a diasporic dinner table in Mexico City is not intended simply as an explication of de Certeau for a less usual site. While his frameworks are provocative in their imaginative open-endedness, I want to take the conclusion of this article to a somewhat different place and focus on 'bodies that eat'. ${ }^{61}$ As a Jesuit, working for periods of time in Latin America during the late 1960s and early 1970s, de Certeau observes everyday poverty and people's creativity in 'making do', particularly in Brazil. These observations, according to his co-worker Giard, are to provide a strong empirical basis for his later theories of the difference and the 'other'. After all, de Certeau says, 'The place of a tactic belongs to the other'. ${ }^{62}$ As a foundation member of Lacan's Ecole Freudienne, de Certeau continued to be haunted by the 'other' in his writing. ${ }^{63}$ Nevertheless, the materiality of the body, 
particularly the 'different' body is a problematic absence/curious implicit presence in such texts. According to Buchanan:

The body is the baseline of de Certeau's thought, but nowhere does he provide an extensive account of the theory of it, and for the most part, his interest in the body seems only to run skin deep. He is fascinated by tattoos and stigmata for instance, but not the viscera. ${ }^{64}$

In response, we might turn to Luce Giard's eloquent (perhaps romanticised) account of women's nurturing through food in the second volume of The Practice of Everyday Life, included, presumably, to counter criticisms of "indifference" to gender ... evident in much of de Certeau's work'. ${ }^{65}$ However, for my project of exploring small acts of eating, as much as of cooking, at the borders of ethnicity and within 'different' intimate relationships, there are other resources at hand. Postcolonial feminist theory, with its attention both to borders and to bodies that ingest underlines the significance of the embodied encounter with difference that extends beyond de Certeau and Giard's dreamy recall of the domestic kitchen as the 'warm room'66 or Giard's realisation that, unconsciously, and though sensory remembering, she had 'had been invested with the secret, tenancious pleasure of doing-cooking ${ }^{67}$ Instead, I feel I need something more gutsy, and fortunately, Probyn provides this:

Eating ... becomes a visceral reminder of how we variously inhabit the axes of economics, intimate relations, gender, sexuality, history, ethnicity, and class. In this way, we really are what we eat, but equally what, how and with whom we eat radically bites into any stable or molar formation of identity. ${ }^{68}$

So, to take these 'alimentary identities' ${ }^{69}$ right to the border, it seems that postcolonial feminism, while acknowledging its debt to meditative tours taken by Certeau and Giard, offers the challenge of 'different', and equally compelling, paths to explore. ${ }^{70}$ According to Sara Ahmed and others, 'Postcolonial feminist theorists have led the way in theorising 'borderzones' and mestizo identities in relation to the work of migration and inhabitance ... They have made us aware that the greatest movements often occur within the self, within the home or within the family, while the phantasm of limitless mobility often rests on the power of border controls and the policing of who does or does not belong..$^{71}$ Extending de Certeau's 'walking' to 
forms of bordercrossing into the intimate bodywork of postcolonial feminism promises to build strong theoretical apparatus for appreciating the significance of 'alimentary identities'-for translating 'taste' into 'talk' in the company of hungry ghosts. Furthermore, this menu of disaporic eating in Mexico City indicates that even when borderwork is amiably conducted behind closed doors, it draws on contradictions for cultural sustenance. At the same time, the tensions of borderwork-contradictorily and ambivalently_provide intimate possibilities for creative practice. For this article, dreams of a cheese sandwich, or of beans with rice, as tastes of la frontera, must continue as works-in-progress.

Jean Duruz is an Adjunct Senior Research Fellow in the Hawke Research Institute at the University of South Australia. Recent publishing appears in collections and journals such as Food and Foodways in Asia, Cultural Theory in Everyday Practice, Everyday Multiculturalism, Emotion, Space and Society.

\footnotetext{
-NOTES

1 Thomas Fox Averill, Secrets of the Tsil Café: A Novel with Recipes, Penguin, Melbourne, 2001, pp. 7-8.

2 Tony Cohen, Mexican Days: Journey into the Heart of Mexico, Bantam, Sydney, 2006, p. 145.

${ }^{3}$ Henri Lefebvre, Everyday Life in the Modern World, trans. Sacha Rabinovitch, Transaction, New Brunswick, 1984, p. 53.

${ }^{4}$ Michel de Certeau, The Practice of Everyday Life, trans. Steven Rendall, University of California Press, Berkeley, 1984, pp. 92-3.

5 de Certeau, The Practice of Everyday Life, p. 93.

${ }^{6}$ de Certeau, The Practice of Everyday Life, pp. 92-3.

7 Jean Duruz, 'Eating at the Borders: Culinary Journeys', Environment and Planning D: Society and Space, vol. 23, no. 1, 2005, pp. 51-69; Jean Duruz, 'Living in Singapore, Travelling to Hong Kong, Remembering Australia...: Intersections of Food and Place', in Emma Costantino and Sian Supski (eds), Culinary Distinction (Journal of Australian Studies, no. 87), API Network, Perth, 2006, pp. 101-15; Jean Duruz, 'From Malacca to Adelaide: Fragments towards a Biography of Cooking, Yearning and Laksa', in Sidney C.H. Cheung and Tan Chee-Beng (eds), Food and Foodways in Asia: Resource, Tradition and Cooking, Routledge, Abingdon, 2007, pp. 183-200.
} 
8 Ien Ang, On Not Speaking Chinese: Living between Asia and the West, Routledge, London, 2001, pp. 193-201.

${ }^{9}$ Ang, p. 200.

10 de Certeau, The Practice of Everyday Life, pp. 96, 108.

${ }^{11}$ Luce Giard, 'Michel de Certeau in the Americas', A Conference in Celebration of the Twentieth Anniversary of Michel de Certeau's Death, University of California, San Diego, 2006,

<http://literature.ucsd.edu/news/conferences/decerteau/biography.html>; Ben Highmore, Everyday Life and Cultural Theory: An Introduction, Routledge, London, 2002, p. 146.

12 See Kraniauskas, for example, in relation to Bhabha and Canclini. John Kraniauskas, 'Hybridity in a Transnational Frame: Latin-Americanist and Post-colonial Perspectives on Cultural Studies', in Avtar Brah and Annie E. Coombes (eds), Hybridity and its Discontents: Politics, Science, Culture, Routledge, London, 2000, p. 250.

${ }^{13}$ Bob Hodge and John O'Carroll, Borderwork in Multicultural Australia, Allen \& Unwin, Sydney, 2006, p.

37.

14 Sneja Gunew, Haunted Nations: The Colonial Dimensions of Multiculturalisms, Routledge, London, 2004, p. 123; see also Vijay Mishra, Bollywood Cinema: Temples of Desire, Routledge, New York, 2002, pp. 236-37.

15 Elspeth Probyn, Carnal Appetites: FoodSexIdentities, Routledge, London, 2000, p. 4.

16 Gunew, p. 95.

17 Sudesh Mishra, Diasporic Criticism, Edinburgh University Press, Edinburgh, 2006, p. 31.

18 Ang, p. 200.

${ }^{19}$ See, for example, Maria Cristina Bayón, 'Persistence of an Exclusionary Model: Inequality and Segmentation in Mexican Society', International Labour Review, vol. 148, no. 3, 2009, pp. 301-15.

20 Transcript of joint interview with Gini Taylor and René Lee, Adelaide, 2004 (unpublished manuscript in author's possession), pp. 14-15.

21 Transcript of joint interview with Gini Taylor and René Lee, p. 16.

22 Transcript of joint interview with Gini Taylor and René Lee, p. 20.

23 David Burton, 'Curries and Couscous: Contrasting Colonial Legacies in French and British Cooking', in A. Lynn Martin and Barbara Santich (eds), Gastronomic Encounters, East Street Publications, Brompton, SA, 2004, p. 54.

${ }^{24}$ Nicola Humble, Cookbooks and the Transformation of British Food, Faber \& Faber, London, 2005, p. 121.

25 Nicola Humble, pp. 120-1; see also Elizabeth David, Summer Cooking, Penguin, Harmondsworth, 1965, pp. 26-7.

26 Michael Symons, One Continuous Picnic: A Gastronomic History of Australia (second edition),

Melbourne University Press, Melbourne, 2007, pp. 258-62.

27 Time Out: Complete Sydney Guide, Time Out Australia, Sydney, 2000, pp. 29-30. 
28 Transcript of joint interview with Gini Taylor and René Lee.

29 Bernal Diaz, The Conquest of the New Spain, trans. J.M. Cohen, Penguin, Harmondsworth, 1963; Jeffrey Pilcher, Que Vivian Los Tamales: Food and the Making of Mexican Identity, University of New Mexico Press, Albuquerque, 1998, p. 23-4.

${ }^{30}$ See Ghassan Hage, 'At Home in the Entrails of the West: Multiculturalism, "Ethnic Food" and Migrant Home-Building', in Helen Grace, Ghassan Hage, Lesley Johnson, Julie Langsworh and Michael Symonds, Home/World: Space, Community and Marginality in Sydney's West, Pluto Press, Sydney, 1997, pp. 10811; Lisa Law, 'Filipina Women and Geographies of the Senses in Hong Kong'. Ecumene, vol. 8, no. 3, 2001, pp. 278-80; Simon Choo, 'Eating Satay Babi: Sensory Perception of Transnational Movement', Journal of Intercultural Studies, vol. 25, no. 3, 2004, p. 209.

31 Transcript of joint interview with Gini Taylor and René Lee, p. 81.

32 Jean Duruz, 'Food as Nostalgia: Eating the Fifties and Sixties', Australian Historical Studies, vol. 29, no. 113, 1999, p. 237.

33 Hodge and O'Carroll, pp. 37-8.

${ }^{34}$ Sarah Bak-Geller, 'Chinese Cooks and Mexican Tastes: The Encounter of Two Culinary Practices in Mexico's Chinese Restaurants', Journal of the Chinese Overseas, vol. 1, no. 1, 2005, p. 123.

35 Ang, p. 200.

36 Transcript of joint interview with Gini Taylor and René Lee, pp. 60-2.

37 Samantha Clark and Samuel Clark, Moro: The Cookbook, Ebury Press, London, 2001, p. 235.

38 Jean Duruz, 'Haunted Kitchens: Cooking and Remembering', Gastronomica, vol. 4, no. 1, 2004, p. 58; Luce Giard, 'Part II: Doing-Cooking', in Michel de Certeau, Luce Giard and Pierre Mayol, The Practice of Everyday Life: Volume 2, trans. Timothy J. Tomasik, University of Minnesota Press, Minneapolis, 1998, pp. 153-9.

39 Transcript of joint interview with Gini Taylor and René Lee, p. 5.

40 Yi-Fu Tuan, 'Pleasures of the Proximate Senses: Eating, Taste and Culture', in Carolyn Korsmeyer (ed.), The Taste Culture Reader: Experiencing Food and Drink, Berg, Oxford, 2005, pp. 230.

${ }^{41}$ David Y.H. Wu and Sidney C.H. Cheung, 'The Globalization of Chinese Food and Cuisine: Makers and Breakers of Cultural Barriers', in David Y.H. Wu and Sidney C.H. Cheung (eds), The Globalization of Chinese Food, Curzon, Richmond, Surrey, 2002, pp. 6, 10.

42 Transcript of joint interview with Gini Taylor and René Lee, pp. 6-7.

43 Elizabeth Rozin and Paul Rozin, 'Culinary Themes and Variations', in Carolyn Korsmeyer (ed.), The Taste Culture Reader: Experiencing Food and Drink, Berg, Oxford, 2005, p. 35.

44 Ang, p. 44.

45 Transcript of joint interview with Gini Taylor and René Lee, pp. 38, 63.

46 Gunew, p. 107.

47 Gunew, p. 108.

48 de Certeau, The Practice of Everyday Life, p. 108. 
49 Transcript of joint interview with Gini Taylor and René Lee, pp. 10-11.

50 Pilcher, p. 140.

51 Transcript of joint interview with Gini Taylor and René Lee, pp. 12-13.

52 Transcript of joint interview with Gini Taylor and René Lee, p. 17.

53 Hage, p. 112.

54 de Certeau, The Practice of Everyday Life, p. 96.

55 Amanda Wise, 'Everyday Multiculturalism: Transversal Crossings and Working Class

Cosmopolitanisms', in Amanda Wise and Selvaraj Velayutham (eds), Everyday Multiculturalism,

Palgrave Macmillan, Basingstoke, Hants, 2009, p. 24.

56 Tim Edensor, citing Rojek in 'The Culture of the Indian Street', in Nicholas R. Fyfe (ed.), Images of the Street: Planning, Identity and Control in Public Space, Routledge, London, 1998, p. 219; see also Meaghan Morris, 'Banality in Cultural Studies', in Simon During (ed.), The Cultural Studies Reader, third edition, Routledge, London, 2007, pp. 138-40.

57 Edensor, pp. 217-18.

58 Tony Bennett, cited in Highmore, p. 154.

${ }^{59}$ Highmore, p. 159; see also pp. 154-6.

60 Ian Buchanan, Michel de Certeau: Cultural Theorist, Sage, London, 2000, p. 94.

61 Probyn, p. 11.

62 de Certeau, The Practice of Everyday Life, p. xix.

63 Michel de Certeau, Culture in the Plural, trans. Tom Conley, University of Minnesota Press,

Minneapolis, 1997; Michel de Certeau, Heterologies: Discourse on the Other, trans. Brian Massumi, University of Minnesota Press, Minneapolis, 1986.

64 Buchanan, p. 81.

65 Highmore, p. 173.

${ }^{66}$ Michel de Certeau and Luce Giard, 'Private Spaces', in Michel de Certeau, Luce Giard and Pierre Mayol (eds), The Practice of Everyday Life: Volume 2, trans. Timothy Tomasik, University of Minnesota Press, Minneapolis, 1998, p. 148.

67 de Certeau and Giard, p. 153.

68 Probyn, p. 9.

69 Probyn, p. 32.

70 Probyn, p. 38; Gunew, pp. 95-6.

${ }^{71}$ Sara Ahmed, Claudia Castañeda, Anne-Marie Fortier and Mimi Sheller, 'Introduction: Uprootings/Regroundings: Questions of Home and Migration', in Sara Ahmed, Claudia Castañeda, Anne-Marie Fortier and Mimi Sheller (eds), Uprootings/Regroundings: Questions of Home and Migration, Berg, Oxford, 2003, p. 5. 